\title{
Implementasi Pendidikan Karakter Kristen di Era Digital
}

\author{
Desi Arisandi Laga Nguru', Indrilily Rambu Oru², Munatar Kause ${ }^{3}$ \\ ${ }^{1,2,3}$ Sekolah Tinggi Agama Kristen Teruna Bhakti, Yogyakarta \\ Correspondence: munatarmoses@gmail.com
}

\begin{abstract}
The purpose of this research is to analyze the concept of Christian character education which refers to the character of Christ adapted to the conditions of the digital era. The current massive technological development opens up all information, so it tends to be difficult to filter, so that information with positive and negative content is very easy to find. The limitations of currently existing technology filtering are a problem in the digital era, where the role of educators is very important, especially in shaping a person's character, in this case, students. Because the formation of a person's character starts from what the person thinks. Like the quote from Samuel Smile's theory that "Sow thoughts and you will reap deeds, sow deeds then you will reap habits, sow habits so you will reap a character, and sow character so you will reap the future". A person's future is very much influenced by the thoughts he creates, if the thoughts that are formed from the beginning are good thoughts then he will certainly have a good character and vice versa. If it is associated with Christian character, then people who follow or have the character of Christ will find the kingdom of God.
\end{abstract}

Keywords: character educational; Christian character; Christian education; the digital age

\begin{abstract}
Abstrak: Tujuan dari penelitian ini adalah menganalisis konsep pendidikan karakter Kristen yang mengacu pada karakter Kristus yang disesuaikan dengan kondisi era digital. Perkembangan teknologi yang sangat masif saat ini, membuka semua informasi, sehingga cenderung mulai susah untuk dilakukan penyaringan, sehingga informasi dengan konten positif dan negatif sangat mudah untuk ditemukan. Keterbatasan penyaringan teknologi yang ada pada saat ini menjadi permasalahan di era digital, di mana peran pendidik menjadi sangat penting, terutama dalam membentuk karakter seseorang, dalam hal ini peserta didiknya. Karena terbentuknya karakter seseorang dimulai dari apa yang dipikirkan orang itu sendiri. Seperti kutipan teori Samuel Smile bahwa "Taburkanlah pikiran maka kamu akan menuai perbuatan, taburkanlah perbuatan maka kamu akan menuai kebiasaan, taburkanlah kebiasaan maka kamu akan menuai karakter, dan taburkanlah karakter maka kamu akan menuai masa depan". Masa depan seseorang sangat dipengaruhi oleh pikiran yang diciptakannya, jika pikiran yang dibentuk dari awal adalah pikiran yang baik maka dia akan dipastikan memiliki karakter yang baik dan begitu juga berlaku sebaliknya. Jika dikaitkan dengan karakter Kristen, maka orang yang mengikuti atau memiliki karakter Kristus kelak menemukan kerajaan Allah.
\end{abstract}

Kata Kunci: karakter Kristiani; pendidikan karakter; pendidikan Kristen; era digital

\section{Pendahuluan}

Perkembangan teknologi pada saat ini berkembang dengan sangat cepat. Berdasarkan data dari APJII (Asosiasi Pengguna Jasa Internet Indonesia) jumlah pengguna internet di Indonesia pada tahun 2019 mencapai 171,17 juta jiwa atau sekitar 64,8\%. ${ }^{1}$ Dari hasil survei tersebut juga ditemukan bahwa pengguna internet mayoritas adalah masyarakat dengan rentang usia 15 hingga 19 tahun. Internet membuka segala hal yang berkaitan dengan data.

\footnotetext{
${ }^{1}$ APJII, Buletin APIII Edisi Januari 2019, 2019.
} 
Data diolah menjadi konten. ${ }^{2}$ Konten-konten yang tersedia di internet ada yang positif dan negatif. Konten yang tersebar melalui jaringan internet ini sama sekali tidak ada yang bisa menahannya baik si penyedia atau si pengguna.

Menurut analisa yang dilakukan oleh Pike M pada tahun 2010, manusia akan melakukan tindakan yang tidak terpuji karena dipengaruhi oleh karakter seseorang yang terbentuk sejak masih kecil. ${ }^{3}$ Kutipan dari Samuel Smiles pun mengatakan bawah "Taburkanlah pikiran, maka kamu akan menuai perbuatan; taburkanlah perbuatan, maka kamu akan menuai kebiasaan; taburkanlah kebiasaan, maka kamu akan menuai karakter, taburkanlah karakter, maka kamu akan menuai masa depan". ${ }^{4}$ Berdasarkan kutipan Samuel Smiles, masa depan seseorang sangat dipengaruhi oleh pikiran yang diciptakannya, jika pikiran yang dibentuk dari awal adalah pikiran yang baik maka dia akan dipastikan memiliki karakter yang baik dan begitu juga berlaku sebaliknya. Jika dikaitkan dengan karakter Kristen, maka orang yang mengikuti atau memiliki karakter Kristus kelak menemukan kerajaan Allah.

Daniel Nuhamara, pada tahun 2018, pernah melakukan penelitian mengenai Pengutamaan Dimensi Karakter Dalam Pendidikan Agama Kristen. Penelitian yang dilakukan tersebut mengungkapkan Pendidikan Agama Kristen yang dilakukan pada saat ini lebih mengarahkan pada konteks textbook mengikuti pakem kurikulum yang ada. Tidak ditemukan nilai-nilai karakter yang ada di dalamnya. Semua hanya berbicara mengenai hafalan ayat Alkitab. Hasil dari penelitian ini adalah sebuah rancangan desain Pendidikan Agama Kristen dengan mengarahkan pada sudut pandang karakter. ${ }^{5}$ Penelitian berikutnya dilakukan oleh Wulandari dan Kristiawan pada tahun 2017. Penelitian yang dilakukan adalah membuat sebuah strategi untuk menguatkan pendidikan karakter. Pemaksimalan yang dilakukan adalah menggunakan peran serta dari orangtua dalam mendidik anak. Peran orangtua sangat dibutuhkan dalam menjalankan strategi ini. Berdasarkan penelitian ini, hasilnya menunjukkan bahwa anak yang memiliki jam bertemu dengan orangtua yang lebih banyak maka pertumbuhan karakternya pun semakiin baik. ${ }^{6}$

Dengan melihat latar belakang dan referensi yang telah ada, belum ditemukan penelitian yang berhubungan dengan Pendidikan Agama Kristen mengenai Pendidikan Karakter Kristen yang terjadi di era digital. Mengacu pada hal tersebut, dalam penelitian ini dilakukan analisis desain pendidikan karakter Kristen di Era Digital yang merujuk pada karakter Kristus.

\section{Metode Penelitian}

Penelitian ini dilakukan dengan pendekatan kualitatif, khususnya dengan metode deskriptif dan analisis. Di dalam penelitian ini akan menggunakan sumber literatur (pustaka) yang ada seperti Alkitab, buku-buku cetak dan elektronik yang berhubungan dengan pendidikan karakter Kristen dan kehidupan di era digital atau Teknologi Informasi.

\footnotetext{
${ }^{2}$ Hermawan Kartajaya and Tim Redaksi Marketeers, Citizen 4.0: Menjejakkan Prinsip-Prinsip Pemasaran Humanis Di Era Digital, Cetakan ke. (Jakarta, 2018).

${ }^{3}$ Mark Pike, "Christianity and Character Education: Faith in Core Values?," Journal of Beliefs \& Values 31 (2010): 311-321.

${ }^{4}$ Sean Covey, The Seven Habits of Highly Effective Teens (Simon \& Schuster, 2011).

${ }^{5}$ Daniel Nuhamara, "Pengutamaan Dimensi Karakter Dalam Pendidikan Agama Kristen," Jurnal Jaffray 16 (2018): 93

${ }^{6}$ Yeni Wulandari and Muhammad Kristiawan, "Strategi Sekolah Dalam Penguatan Pendidikan Karakter Bagi Siswa Dengan Memaksimalkan Peran Orang Tua," JMKSP 2 (2017).
} 


\section{Pembahasan}

Fungsi dari pendidikan karakter dapat dilihat dari sejarahnya yaitu perang melawan lupa. Mula-mulanya, aktivitas di dalam pendidikan telah dijadikan sebagai cara bertindak dari masyarakat. Manusia mewariskan nilai yang menjadi bagian penting dari budaya masyarakat dimana tempat mereka hidup dan mewariskan nilai kepada generasi selanjutnya. ${ }^{7}$ Samuel Smile pernah mengatakan bahwa "Taburkanlah pikiran, maka kamu akan menuai perbuatan. Taburkanlah perbuatan maka kamu akan menuai kebiasaan. Taburkanlah kebiasaan maka kamu akan menuai karakter. Taburkanlah karakter maka kamu akan menuai masa depan". ${ }^{8}$ Dengan pernyataan dari Samuel Smile tersebut, maka dipastikan bahwa karakter seseorang dimulai dari apa yang dipikirkannya. Sebagai pendidik dan orangtua, maka sangat penting untuk memperhatikan apa yang dikonsumsi oleh anak. Hal yang dikonsumsi oleh anak akan menjadi apa yang dipikirkannya. Jika hal baik yang dikonsumsi oleh anak, maka pikiran dan perbuatan yang dilakukan anak itu juga akan menjadi baik. Jika perbuatan baik itu dilakukan terus menerus dan menjadi kebiasaan yang baik, maka perbuatan baik itu pula yang akan menjadi karakter dari anak itu sendiri. Jika anak memiliki karakter yang baik dipastikan dia memiliki masa depan yang baik juga. Berlaku juga sebaliknya, dimulai dari awal lagi untuk hal yang tidak baik, jika hal buruk yang dikonsumsi oleh anak maka akan berdampak semakin buruk yang mengakibatkan masa depannya juga buruk.

\section{Persoalan Pendidikan Karakter di Indonesia}

Permasalahan pendidikan karakter di Indonesia hingga saat ini menyangkut pendidikan moral dan dalam aplikasinya terlalu membentuk satu arah pembelajaran khusus sehingga melupakan mata pelajaran lainnya. Dalam pembelajaran yang terjadi, pembentukan terjadi pada satu sudut kurikulum yang diringkas kemudian diolah sehingga menjadi pembelajaran yang siap saji. Pendidik dalam hal ini guru masih memiliki kecenderungan untuk mengarahkan prinsip-prinsip moral yang umum secara one-way atau satu arah, tanpa melibatkan partisipasi siswa untuk bertanya dan mengajukan pengalaman empiriknya. ${ }^{9}$ Hingga saat ini dalam proses pendidikan di Indonesia yang berorientasi terhadap pembentukan karakter individu masih belum tercapai karena pada prosesnya, pendidikan di Indonesia masih mengedepankan penilaian pencapaian individu dengan tolak ukur tertentu terutama logik-matematik sebagai ukuran utama yang menempatkan seseorang sebagai warga kelas satu. Pada kenyataan yang terjadi, pendidikan karakter yang berorientasi pada moral dikesampingkan sehingga mengakibatkan adanya banyak kegagalan yang nyata dalam dimensi pembentukan karakter individu. ${ }^{10}$

\section{Dasar Teologis Pendidikan Karakter}

Campur tangan Allah dalam sejarah manusia dimulai pada kisah Musa, mengapa? Karena kesaksian tentang tokoh Musa adalah kesaksian oleh komunitas, bukan kesaksian individual seperti yang terjadi pada tokoh Abraham. Sejarah Kerajaan Allah di dunia dimulai dari kisah panggilan Musa (Kel. 2:23-3:22). Alkitab mencatat dalam Keluaran 2 dan 3 bahwa inisiatif awal panggilan manusia untuk ambil bagian dalam misi Allah datannya dari diri Allah sendiri. Inilah inti dari konsep keselamatan (soteriologi) Kristen yaitu bukan manusia yang

\footnotetext{
${ }^{7}$ Ibid.

${ }^{8}$ Jason Ohler, "Digital Citizenship Means Character Education for the Digital Age," Kappa Delta Pi Record 47 (2011): 25-27.

${ }^{9}$ Ibid.

${ }^{10}$ Ibid.
} 
mencari Tuhan melainkan Tuhan yang mencari manusia. Hal ini didukung oleh perkataan Tuhan Yesus dalam Yohanes 15:16 yang berbunyi: "Bukan kamu yang memilih Aku, tetapi Akulah yang memilih kamu...supaya kamu pergi dan menghasilkan buah..."

Sejarah Kerajaan Allah dimulai dari Kisah Musa yang dipanggil Allah untuk menunaikan Misi Allah yaitu membebaskan bangsa Israel dari tanah perbudakan di Mesir. Dalam perjumpaan dengan Allah, Musa harus mengambil keputusan terhadap pilihan apakah ia harus mengikuti panggilan Allah atau mengikuti misinya sendiri. Dalam ketidakpastian dan ketidakmengertian Musa, ia belajar untuk percaya kepada Tuhan atau berangkat dari iman dan bukan dari pengertiannya sendiri. Inilah titik berangkat yang penting untuk memahami misi Allah dalam diri manusia yaitu bukan mengerti dulu baru percaya, melainkan percaya dulu baru mengerti. Di sinilah yang menjadi dasar karakter yang digunakan dalam penelitian ini yaitu bagaimana Ketaatan Musa kepada Tuhan untuk percaya pada Tuhan, demikian juga dengan Tanggung jawab Musa saat untuk menyelesaikan misi dari Tuhan untuk membebaskan bangsa Israel dari tanah perbudakan, dan Kepedulian Musa terhadap bangsa Israel saat mengatarkan bangsa Israel ke tanah perjanjian.

\section{Karakter Kristus}

Karakter Kristus adalah karakter paling ideal yang ada di alam semesta ini bagi umat Kristiani. Namun, untuk melaksanakan proses karakter dengan mencontoh Yesus tidaklah mudah dan sebaliknya malah membahayakan dan penuh ancaman. Tuhan telah meminta kita agar menjadi taat dan setia kepada-Nya, karena la telah memilih kita untuk menjadi milik-Nya sejak semula. Roma 8:29 "Sebab semua orang yang dipilih-Nya dari semula, mereka juga ditentukan-Nya dari semula untuk menjadi serupa dengan gambaran anak-Nya, supaya la, Anak-Nya itu, menjadi yang sulung diantara banyak saudara." Gambaran sosok Yesus bukan hanya untuk diikuti saja namun menjadi bentuk penyerahan kita kepada Tuhan. Mengikuti Kristus merupakan misi dari Allah, maka Allah juga yang akan melengkapi apa yang dibutuhkan. Kesadaran inilah yang perlu dibangun yaitu bahwa seseorang yang menjalankan misi Tuhan, maka ia harus mau dipimpin oleh Roh Tuhan, mau diintervensi (diubah) oleh-Nya dan mengarahkan kehidupannya kepada Allah dan bukan kepada diri sendiri. Ini adalah ibadah sejati11.

Ada begitu banyak pelajaran yang terkait dengan perjalanan kehidupan Yesus Kristus selama hidup di dunia, yang juga merupakan gambaran dari karakter Kristus yang seharusnya diikuti oleh pengikut Kristus. Beberapa karakter Kristus yang ditemukan di dalam Alkitab antara lain12: penuh perhatian, hidup sederhana, hidup kaya tanpa ketamakan, berani, penuh pertimbangan, tegas, berbelas kasih, tidak butuh ketenaran, tahan godaan, selalu puas dan bersyukur, pemaaf, rendah hati, penyabar, sanggup dianiaya, tulus hati. Berdasarkan 15 karakter Kristus tersebut diatas, untuk lebih dapat lebih rinci dan mudah dipahami, maka dapatlah dibagi lagi menjadi tiga bagian yaitu: Taat, tanggung jawab, peduli. Pengelompokan ini dilakukan sebagai berikut:

${ }^{11}$ Tim Pendidikan Karakter Tirtamarta, Pendidikan Karakter Kristiani Tirtamarta (Jakarta: Tirtamarta-BPK Penabur, 2017).

${ }^{12}$ Redaksi Tuhan Yesus Org, "15 Karakter Kristus Dalam Alkitab Sebagai Manusia," TuhanYesus.Org, last modified 2020, accessed October 30, 2020, https://tuhanyesus.org/karakter-kristus. 
Tabel 1: Pengelompokan Karakter Kristus

\begin{tabular}{|l|l|}
\hline Kelompok & Karakter Kristus \\
\hline \multirow{3}{*}{ Taat } & Hidup sederhana \\
& Hidup kaya tanpa ketamakan \\
& Tidak Butuh Ketenaran \\
& Tahan Godaan \\
& Selalu puas dan bersyukur \\
\hline \multirow{3}{*}{ Tanggung Jawab } & Berani \\
& Penuh Pertimbangan \\
& Sanggup dianiaya \\
\hline \multirow{3}{*}{ Peduli } & Penuh perhatian \\
& Tegas \\
& Berbelas kasih \\
& Pemaaf \\
& Rendah hati \\
& Penyabar \\
& Tulus hati \\
\hline
\end{tabular}

\section{Taat}

Dalam perjanjian Lama, kata taat ditulis dalam bahasa Ibrani dengan kata "Syema". Secara harafiah kata ini berarti mendengar. Ketaatan adalah respon seseorang ketika mereka mendengarkan orang yang mempunyai pengaruh dan kuasa atas dirinya. Dalam Perjanjian Baru, Ketaatan ditulis dengan kata "Hupekoos" yang secara harafiah berarti mendengarkan perintah. Kata "Hupekoos" dalam masyarakat sekuler digunakan untuk menjelaskan tugas seorang pelayan penjaga pintu yang harus mendengarkan baik-baik siapa yang mengetuk pintu rumah tuannya. Ketaatan erat kaitannya dengan "mendengar". Filipi 2:8 mencatat ketaatan Tuhan Yesus, "Ia merendahkan dirinya dan taat sampai mati." Dari catatan tentang ketaatan Tuhan Yesus ini, dapatlah dipahami bahwa orang yang taat itu adalah orang yang mendengar dan melakukan perintah secara tepat dan cepat.

Musa pun mendengarkan perintah Tuhan dan bersedia melaksanakannya. Dalam melaksanakan misi Tuhan, Musa membuka diri untuk dibimbing roh Allah dan diperlengkapi Allah (dengan kuasa dan keberanian). Karena itu Musa selalu melibatkan Tuhan dalam seluruh hidupnya. Musa hidup dan bergaul dengan Tuhan, sehingga ia berpartisipasi aktif dalam menjalankan misi Tuhan yaitu membebaskan bangsa Israel dari Mesir.

Berdasarkan konsep atau pemahaman nilai Taat ini, maka karakter profil yang diharapkan dari seseorang yang Taat adalah sebagai sebagai berikut: Melibatkan Tuhan dalam setiap kegiatan; Mengikuti kegiatan ibadah (bergaul dengan Tuhan); Berpartisipasi aktif dalam pelayanan.

\section{Tanggung Jawab}

Tanggung jawab dalam bahasa Ibrani adalah "Acharayut", yang berasal dari kata "acher" (other). Menerima tanggung jawab berarti menumbuhkan kemampuan untuk merespon terhadap kebutuhan orang lain. Tanggung jawab terhadap orang lain muncul pada saaat di mana tidak ada orang lain yang mau mengambil tanggung jawab tersebut. Para rabi belajar mengenai tanggung jawab tersebut dari diri Musa (Kel. 2:12). Ketika Musa melihat saudara-saudaranya mendapat perlakuan kasar dari para mandor bangsa Mesir, Musa tidak diam saja. Dia segera bertindak karena ia tahu apa yang dilakukan sang mandor adalah perbuatan yang salah.

Tanggung jawab dalam bahasa Inggris adalah Responsibility, yang diartikan sebagai kewajiban untuk melakukan sesuatu yang menjadi bagian dari peran atau tugasnya. Dalam Kamu Besar Bahasa Indonesia, tanggung jawab adalah keadaan wajib menanggung segala sesuatunya. Kata "wajib" berasal dari kata Yunani "opheilo" yang mengandung arti berhutang. 
Dalam Yohanes 13:12-17, murid-murid wajib melakukan prosesi saling membasuh kaki sesama murid, tidak boleh tidak, karena hal itu adalah hutang satu dengan yang lain dan mereka tidak punya alasan untuk tidak melakukannya, karena Yesus sendiri telah memberikan contoh dan melakukannya terhadap mereka.

Berdasarkan konsep atau pemahaman nilai Tanggung jawab di atas maka karakter profil yang diharapkan adalah: Jujur dalam tindakan dan tutur kata; Bersikap benar; Bersedia menyelesaikan konflik; Memiliki kepercayaan diri dalam menjalankan tugas dan menghadapi masalah.

\section{Peduli}

Dalam Perjanjian Lama, kata yang dipakai untuk mewakili kepedulian adalah "Darash" yang berarti tanah di mana Tuhan, Allahmu memelihara (UI. 11:12). Pemakaian kata kepedulian di sini menunjuk pada pemeliharaan Allah atas negeri yang akan dimasuki oleh umat pilihan Allah. Allah atas negeri yang akan dimasuki oleh umat pilihan Allah. Allah menunjukkan kepedulian terhadap kehidupan umat dengan janji-Nya bahwa ketika mereka hidup taat pada perintah-Nya, maka mereka akan memasuki suatu negeri yang baik keadaannya. Sebuah negeri yang menghasilkan bahan makanan tanpa perlu berjerih payah.

Kata kepedulian dalam bahasa Inggris diartikan sebagai "care". Dalam perjanjian baru berbahasa Yunani, menggunakan kata "epimeleomai" yang artinya memelihara. Lukas 10:3435, bercerita tentang orang Samaria yang murah hati. Orang yang dipinggirkan dapat menyatakan kepeduliannya tanpa adanya motivasi untuk mencari pujian. la mempedulikan orang lain dengan tulus tanpa meminta dan berharap balasan dari orang lain. Dalam kisah Alkitab, salah satu bentuk kepedulian Allah diwujudkan melalui Musa yang dipilih untuk membebaskan bangsa Israel dari tanah Mesir. Musa adalah contoh yang mau mencari dan mendengar kehendak Tuhan serta tergerak untuk memberi pertolongan bagi sesama dan menghargai sesama sekaligus lingkungannya.

Dalam perjalanan hidup-Nya di dunia, ditemukan bahwa Yesus sangat peduli dengan kehidupan manusia. Bahkan dinyatakan bahwa la menjalani semua proses penyelesaian misiNya sebagai Juruselamat tidak terlepas dari rasa peduli-Nya yang sangat besar terhadap manusia yang berdosa. Hal ini dapat dilihat ketika Yesus menyembuhkan berbagai muzijat, baik itu menyembuhkan orang sakit, membangkitkan orang mati, dan juga saat la menyelesaikan masalah-masalah yang terjadi disekelingnya seperti mengubah air menjadi anggur, memberi makan 5000 orang, meredakan angin badai, dan masih banyak lagi.

Berdasarkan konsep atau pehaman nilai Peduli di atas maka karakter profil yang diharapkan adalah: Memberi pertolongan; Mendengar dengan penuh perhatian; Menghargai sesama dan lingkungan.

\section{Era Digital}

Era Digital ditandai dengan transformasi sosio-ekonomi yang intens dalam skala yang mirip dengan Revolusi Industri. Kehidupan sehari-hari melibatkan interaksi sosial ekonomi yang lebih bervariasi dari sebelumnya, menyebabkan perputaran pengetahuan sosial ekonomi lebih cepat. Era ini semakin dikaitkan dengan teknologi informasi dan komunikasi (TIK), yang fungsinya semakin mampu memobilisasi pengetahuan, dengan kecepatan lebih cepat, dan dengan cara yang dapat membuat ketagihan. ${ }^{13}$

\footnotetext{
${ }^{13}$ Jill Shepherd, What Is the Digital Era? (Strathclyde: University of Strathclyde, 2004).
} 
Di dalam dunia pendidikan sendiri saat ini sudah sudah banyak dan tidak asing lagi memanfaatkan media online agar proses belajar mengajar tetap berjalan. Ditambah lagi saat ini penggunaan media digital semakin masif dengan adanya kondisi pandemi Covid-19 yang sudah berlangsung cukup lama baik itu di Indonesia maupun di dunia pada umumnya, membuat semua aspek kegiatan memaksa untuk bekerja dari rumah dan memanfaatkan media online. Namun sebelum proses belajar ini terjadi, anak pada zaman sekarang ini sudah memanfaatkan gadgetnya terlebih dahulu sehingga pemanfaatan belajar-mengajar dirasa seperti kegiatan sekunder dalam menggunakan gadget-nya. Game online, sosial media dan youtube menjadi konsumsi utama anak-anak tersebut.

\section{Permasalahan Digitalisasi bagi Anak}

Dalam laporan yang dilakukan oleh UNICEF dalam The State of the World's Children 2017: Children in a digital world mengidentifikasi berbagai macam fakta yang berhubungan dengan penggunaan perangkat digital antara lain:14

1. Remaja dengan usia 15-24 adalah kelompok usia pengguna perangkat. $48 \%$ dari keseluruhan populasi di dunia, $71 \%$ sudah terhubung dengan internet dan $29 \%$ nya adalah remaja tersebut.

2. Anak-anak mengakses internet pada usia yang semakin muda. Di beberapa negara, anak-anak di bawah 15 tahun cenderung menggunakan internet seperti orang dewasa di atas 25 tahun.

3. Teknologi digital memberikan kesempatan belajar dan pendidikan bagi anak-anak, terutama di daerah terpencil dan selama krisis kemanusiaan.

4. Kira-kira 56 persen dari semua situs web berbahasa Inggris. Banyak anak tidak dapat menemukan konten yang mereka pahami atau yang relevan.

5. Lebih dari 9 dari 10 URL pelecehan seksual terhadap anak-anak yang diidentifikasi secara global dihosting di lima negara - Kanada, Prancis, Belanda, Federasi Rusia, dan Amerika Serikat.

Secara umum, era digital menjadi lahan yang berbahaya untuk usia anak. Jika tidak ada pendampingan dari orangtua maka akan berdampak buruk bagi perkembangan anak. Berikut ini adalah beberapa konten bahaya dunia digital yang dikutip dari data UNICEF15: konten kekerasan (menyakiti diri sendiri, bunuh diri, diskriminasi, radikalisasi, bullying); konten seksual (pornografi, pelecehan seksual, produksi dan konsumsi materi pelecehan anak, produksi gambar tidak senonoh oleh anak); eksploitasi komersial (marketing terselubung, biasa ditemukan dalam game, perjudian online, pelanggaran dan penyalahgunaan data pribadi, peretasan, penipuan dan pencurian, pemerasan seksual, perdagangan untuk tujuan seksual, eksploitasi anak).

\section{Desain Karakter Kristus Sesuai Kondisi Era Digital}

Pada penelitian yang dilakukan saat ini, pendidikan karakter Kristen dengan parameter yang telah dikelompokkan menjadi tiga karakter Kristus yaitu: Taat, Tanggung Jawab, dan Peduli, akan disesuaikan dengan konteks dunia digital yang dihadapi oleh anak. Ketiga karakter Kristus ini masing-masing memiliki profil yang telah disebutkan di atas. Profil tersebut akan digunakan sebagai pondasi dasar desain pendidikan karakter Kristen di Era Digital. Berikut ini adalah pondasi desain yang dilakukan:

\footnotetext{
${ }^{14}$ UNICEF, The State Of The World's Children 2017: Children in a Digital World, 2017.

15 Ibid.
} 
Tabel 2. Pondasi desain Karakter Kristen

\begin{tabular}{|l|l|}
\hline Karakter & \multicolumn{1}{|c|}{ Profil } \\
\hline \multirow{3}{*}{ Taat } & $\begin{array}{l}\text { Melibatkan Tuhan dalam setiap kegiatan } \\
\text { Mengikuti setiap kegiatan ibadah (bergaul dengan Tuhan) } \\
\text { Berpartisipasi aktif dalam pelayanan. }\end{array}$ \\
\hline \multirow{3}{*}{ Tanggung jawab } & $\begin{array}{l}\text { Jujur dalam tindakan dan tutur kata } \\
\text { Bersikap benar } \\
\text { Bersedia menyelesaikan konflik } \\
\text { Memiliki kepercayaan diri dalam menjalankan tugas dan } \\
\text { menghadapi masalah }\end{array}$ \\
\hline & $\begin{array}{l}\text { Memberi pertolongan } \\
\text { Mendengar dengan penuh perhatian } \\
\text { Penghargai sesama dan lingkungan }\end{array}$ \\
\hline
\end{tabular}

Dari pendeskripsian karakter menjadi profil, hal yang perlu dilakukan adalah bagaimana melakukan penyesuaian dengan kondisi era digital.

\section{Taat}

Melibatkan Tuhan dalam setiap kegiatan. Pendidik harus membiasakan siswa untuk berdoa terlebih dahulu sebelum proses belajar mengajar dilakukan. Apapun kegiatan online yang dilakukan diharapkan anak dapat mengimplementasikannya. Mengapa hal ini menjadi penting? Kegiatan online sudah seperti kegiatan makan, setiap makan berdoa dulu mengucap syukur dan mengharapkan berkat makanan itu bisa menjadi kesehatan dan kekuatan. Demikian juga dengan kegiatan online, mengucap syukur karena masih bisa belajar walaupun tidak dapat bertatap muka, mengetahui keadaan temannya dan guru lewat perangkat yang digunakan, karena sudah diberikan perangkat yang bisa digunakan, internet yang lancar, meminta perlindungan Tuhan agar pada saat kegiatan belajar online dijauhkan dari hal buruk.

Mengikuti setiap kegiatan ibadah. Membiasakan siswa untuk mengikuti kegiatan ibadah baik secara offline ataupun online akan menjadikan kebiasaan bagi siswa. Permasalahan yang sering terjadi pada siswa adalah kurang fokusnya siswa dalam mengikuti ibadah. Untuk mengatasi permasalahan ini, maka sangat diperlukan inovasi yang dapat dilakukan baik dari pihak sekolah ataupun gereja menciptakan ibadah ataupun renungan yang dapat membuat siswa merasa senang dan nyaman.

Berpartisipasi aktif dalam pelayanan. Siswa dapat berpartisipasi dalam pelayan. Bentuk dari partisipasi pelayanan sangat banyak termasuk dalam kegiatan online. Pelayanan ini memiliki maksud mempersembahkan apa yang bisa dilakukan siswa kepada Tuhan. Sebagai contoh guru dapat memberikan tugas pelayanan menyanyi lagu pujian yang direkam, membagikan renungan harian dan lain sebagainya yang dapat dibagikan di internet.

\section{Tanggung Jawab}

Jujur dalam tindakan dan tutur kata. Guru dapat mengajarkan dan mengarahkan siswa untuk melakukan selalu sikap jujur dalam melakukan kegiatan, sebagai contoh tidak melakukan plagiasi atau duplikasi saat mengerjakan tugas. Dalam hal ini guru juga wajib memberitahukan akibat jika tidak jujur dalam melakukan tindakan. Kebebasan dalam berekspresi adalah hal yang mutlak di dunia maya sehingga banyak sekali berita hoax yang bertebaran di dunia maya. Tidak ada yang bisa menahannya, hanya hukum yang berlaku yang dapat menindaknya. Untuk itu guru harus memberitahukan dan mengarahkan siswa untuk selalu membuat konten yang sehat dan positif. 
Bersikap benar. Bersikap benar di dunia digital merupakan hal yang cukup sulit dilakukan termasuk oleh orang dewasa. Ketika ada suatu informasi yang beredar belum diketahui kebenarannya maka sebaiknya tidak langsung merespon atau membagikannya kepada orang lain. Ketika seseorang menemukan konten negatif seperti konten pornografi, perjudian dan lain sebagainya, saat itu juga menutup konten tersebut. Guru bertugas untuk mengarahkan siswa untuk tidak membuka konten tersebut dan jika konten tersebut terbuka maka harus langsung menutupnya. Guru wajib memberitahukan akibat jika siswa tetap membuka konten tersebut contohnya menyebabkan ketagihan dan apa yang dilakukan siswa tersebut memalukan karena dilihat juga oleh Tuhan.

Bersedia menyelesaikan konflik. Dalam hal ini, penyelesaian konflik di dunia maya sering disalah artikan seperti seorang penengah. Konflik di sini adalah bagaimana seseorang merespon suatu konten yang negatif atau layak berada di internet dengan melaporkan atau mereport bahwa konten yang ditemukan adalah konten negatif. Guru dapat memberikan contoh bagaimana merespon sebuah konten yang tidak layak dikonsumsi. Orang yang tahu tapi hanya diam lebih berdosa daripada orang yang menyebarkan konten negatif.

Memiliki kepercayaan diri dalam menjalankan tugas dan menghadapi masalah. Kepercayaan diri sangat dibutuhkan dalam menghadapi era digital. Korban cyber bullying sering terjadi karena keragu-raguan seseorang dalam menghadapi masalah. Sebagai contoh, ketika seorang anak membuat sebuah konten pasti akan ada suatu momen orang lain yang melihat merasa tidak senang dengan konten yang dibuat oleh anak itu, biasanya yang terjadi adalah ucapan kebencian hingga pembullian. Guru dapat mengarahkan siswa agar selalu merasa dalam lindungan Tuhan. Dengan lindungan Tuhan semua akan baik-baik saja.

\section{Peduli}

Memberi pertolongan. Membiasakan anak untuk melakukan pertolongan kepada orang lain akan membiasakan anak untuk menjadi orang yang peduli terhadap sesama. Berbagai macam hal yang dapat dilakukan untuk memberi pertolongan di dunia digital sebagai contoh memberikan donasi melalui yayasan donasi resmi untuk orang yang membutuhkan bantuan dana biaya berobat, sekolah hingga korban bencana alam.

Mendengar penuh perhatian. Mendengar penuh perhatian dapat dikaitkan dengan memperhatikan dengan seksama secara detail. Dengan perhatian penuh maka anak diharapkan mendapatkan suatu informasi sesuai dengan pemahannya dan dapat menanyakan hal yang tidak dipahaminya kepada guru ataupun orangtua sehingga tidak terjadi adanya misinformasi dari konten yang diterimanya. Hal ini cukup penting mengingat misinformasi ini salah satu penyebab terjadinya berita hoax yang bertebaran di dunia maya.

Menghargai sesama dan lingkungan. Keberadaan sosial media tidak dapat dipungkiri. Sifat sosial media yang terkesan kompetitif yaitu bersaing menampilkan yang terbaik adalah hal yang lumrah. Sifat kompetitif ini sering menyebabkan hilangnya rasa menghargai sesama. Siswa diharapkan yang menggunakan sosial media diharapkan untuk terus mengapresiasi temannya maupun konten-konten positif yang beredar. Selain itu siswa juga diharapkan dapat menghargai dan menjaga lingkungannya. Sebagai contoh siswa memahami bahwa penggunaan kertas secara berlebih dapat merusak penghijauan bumi sehingga siswa memanfaatkan secara maksimal gadget yang dimiliki sebagai media pengganti buku. 


\section{KESIMPULAN}

Hal yang sangat perlu diperhatikan dari Pendidikan Karakter Kristen di era digital ini adalah bagaimana caranya agar karakter Kristus yang sudah dipaparkan di atas dapat menjadi kebiasaan. Pendidik harus terus mendidik dan mengawasi agar hal tersebut dapat diulangi terus-menerus. Dengan perulangan ini, jika taat, tanggung jawab, dan peduli tersebut tertanam dalam pikiran anak-anak secara terus-menerus, maka perbuatan positif tersebut juga pasti akan menjadi kebiasaan. Karena dengan kebiasaan positif yang dilakukan secara terus-menerus, hal positif itulah yang akan menjadi karakter. Dengan karakter yang baik dan dilakukan secara terus-menerus maka seorang anak dapat menyongsong masa depannya yang baik pula.

Selain dari peran pendidik untuk melakukan pengawasan terhadap anak didiknya, sebagai pendidik, diharapkan guru-guru agama Kristen juga dapat juga mengimplementasikan nilainilai karakter Kristus ini dalam kehidupan sehari-hari dan dalam menjalankan profesinya sebagai pendidik, agar anak-anak didik dapat melihat contoh yang nyata yang kemudian akan mudah diikuti atau dijadikan motivasi untuk mereka terus berjuang mewujudkan karakter Kristus dalam kehidupan mereka. Namun demikian, dalam prosesnya, banyak sekali tantangan dan juga kesukaran yang akan dihadapi sebagai pendidik, tetapi alangkah lebih baiknya jika semua kesulitan-kesulitan itu tidak menjadi alasan bagi pendidik untuk tidak terus menerus berusaha mempraktekkan karakter Kristus dalam setiap kehidupannya. Guru Agama kristen sebagai orang yang bertanggung jawab penuh pada apa yang diajarkan hari ini, untuk mendapatkan hasil yang baik dikemudian hari, dalam hal ini akan menghasilkan peserta didik yang sungguh-sungguh melakukan karakter Kristus dalam kehidupannya sehari-hari.

\section{REFERENSI}

APJII. Buletin APJII Edisi Januari 2019, 2019.

Covey, Sean. The Seven Habits of Highly Effective Teens. Simon \& Schuster, 2011.

Kartajaya, Hermawan, and Tim Redaksi Marketeers. Citizen 4.0: Menjejakkan Prinsip-Prinsip

Pemasaran Humanis Di Era Digital. Cetakan ke. Jakarta, 2018.

Koesoema, Doni. Pendidikan Karakter : Mendidik Anak Di Zaman Global. Surabaya: Grasindo, 2006.

Kusumah, Doni. Pendidikan Karakter. Jakarta: Grasindo, 2007.

Milson, A., and L. Mehlig. "Elementary School Teachers Sense of Efficacy for Character Education." Journal of Educational Research 96 (2002): 47-53.

Nuhamara, Daniel. "Pengutamaan Dimensi Karakter Dalam Pendidikan Agama Kristen." Jurnal Jaffray 16 (2018): 93.

Ohler, Jason. "Digital Citizenship Means Character Education for the Digital Age." Kappa Delta Pi Record 47 (2011): 25-27.

Org, Redaksi Tuhan Yesus. "15 Karakter Kristus Dalam Alkitab Sebagai Manusia." TuhanYesus.Org. Last modified 2020. Accessed October 30, 2020. https://tuhanyesus.org/karakter-kristus.

Pike, Mark. "Christianity and Character Education: Faith in Core Values?" Journal of Beliefs \& Values 31 (2010): 311-321.

Prestwich, D. "Character Education in America's Schools." School Community Journal 14, no. 1 (2004): 139-150.

Shepherd, Jill. What Is the Digital Era? Strathclyde: University of Strathclyde, 2004.

Tirtamarta, Tim Pendidikan Karakter. Pendidikan Karakter Kristiani Tirtamarta. Jakarta: Tirtamarta-BPK Penabur, 2017.

UNICEF. The State Of The World's Children 2017: Children in a Digital World, 2017.

Wulandari, Yeni, and Muhammad Kristiawan. "Strategi Sekolah Dalam Penguatan Pendidikan Karakter Bagi Siswa Dengan Memaksimalkan Peran Orang Tua." JMKSP 2 (2017). 